\title{
A Baltic Sea region student poster exhibition on cooperation and conflict in medicine
}

Which topics and developments in the field of medicine and health sciences are relevant for the Baltic Sea macro-region in the future? How can a wider public be involved in the discourses of cooperation within the Baltic Sea region?

Although several research programs have been established to foster research on this territory, surprisingly few publications deal thoroughly with "Baltic" networks in medicine and their impact for the production and spread of knowledge. ${ }^{1}$ A present approach to these issues has been made with a student poster project at the Department for the History, Theory and Ethics of Medicine, Centre for Health and Society, Heinrich-HeineUniversity in Düsseldorf, Germany.

Early 2020 a poster project series started, led by Nils Hansson, Yvonne Gavaller und Felicitas Söhner. In seminars medical students created posters to shed light on innovations, conflicts and collaborations in medicine and aspects of e-health in northern Europe. The posters focus on the transfer of knowledge across the Baltic Sea as well as on the personal relationships between researchers, and not least on political and technological aspects of these developments.

The idea of the student poster project was to realize a traveling exhibition on the topic of cooperation and conflict in medicine in the Baltic Sea region. The results can be seen in a virtual exhibition. ${ }^{2}$

1 Nils Hansson and Jonatan Wistrand, eds., Explorations in Medical History in the Baltic Sea region 1850-2015 (Rochester, NY: University of Rochester Press, 2019).

2 See our webpage on medicine in the Baltic Sea region, accessed September 13, 2021, https://balticmedicine.wordpress.com/ 
Because of the Covid-19 pandemic, the posters were developed in online seminars. Next to posters, the webpage also includes short podcasts by the students that highlights central aspects of their work.

A part of the posters focuses on the entangled history behind the development of new technologies in medicine. For example, there is a poster about the cooperation of the Swedish cardiologist Inge Edler and the German physicist Carl Hellmuth Hertz and the innovation of ultrasound in medicine. Ultrasonic waves had previously only been used in the military and industrial sectors for materials testing. In 1953, Edler and Hertz tested a new method for detecting heart valve motion using this ultrasound waves. Before the diagnosis of heart valve defects was based on anamnesis, percussion, cardiac catheter examination and X-ray treatments. Using these methods, it had not been possible to determine the severity of heart disease. With their M-mode echocardiography, Edler and Hertz paved the way for new noninvasive cardiac diagnostics. It required not only the successful collaboration of the two at Lund University, Sweden. At that time, many technologies such as radar and sonar were available without which this innovation would not have been possible. To emphasize milestones in these developments, the student created timeline with central factors leading the way.

Another thematic focus are networks of politics and medicine. One result is a poster on the laws of sterilization during the first half of the $20^{\text {th }}$ Century with a focus on similarities and differences in Sweden and Germany. They noted that in the public mind, sterilization laws are often associated with the regime of the National Socialists. Based on the observation that forced sterilizations were also legal in other nations, they raised the question to what extent there were differences and similarities in the handling of sterilization laws between Sweden and Germany. Based on primary and secondary literature, they explored this question and created this poster. The students concluded that, all in all, a simple justification of forced sterilizations solely with National Socialism would be inaccurate. They stated that the extent of sterilization in Germany under the Nazi regime was more radical overall compared to Sweden, and at the same time the acceptance of eugenics can be understood as deeply rooted in both countries regardless of the political spectrum. The poster strongly emphasizes that even today, inequality and systemic discrimination of minorities are still rooted in our nations.

The most recent poster-seminar (summer term 2021) had a focus on e-health. The resulting posters deal with the status of digitalisation and e-health in the different countries of the Baltic Sea region, as well as with 
the opportunities and risks of AI in the future and the different status of the integration of e-health in teaching. These e-health issues in particular are raised in the context of the current Covid-19 pandemic.

One result is a poster on the introduction of the electronic health card in Estonia as a role model for implementation in Germany. The authors ask to what extent it would be possible for Germany to adopt the Estonian system as a best-practice case. They note that the implementation of an eHR has the potential to improve effectiveness in the health system, although some scientific studies point at risks and challenges.

Another poster looks at German universities and eHealth and analyses courses and curricula related to e-health offered by German universities. The students conclude that it would be favourable to offer courses in digital health with modern learning approaches and online resources. In their view, the progress in implementing e-health in the curricula at German universities is mediocre. The junior researchers would like to contextualise their findings by comparing them with the situation in other countries in Northern Europe. As little current data is currently available, they plan to expand their study by circulating a questionnaire in Sweden, Latvia and Estonia to learn more about the situation in these countries, which are commonly considered to have a strong digital infrastructure. This will put the German results into context.

We wish to continue the online poster seminar and invite universities within the "Bridging the Baltic" network and beyond to take part in the project to further promote collaboration between medical students in northern Europe.

Felicitas Sohner,

Dr., Medicīnas vēstures, filozofijas un ētikas katedra, Heinriha Heines Universitāte Diseldorfā, Vācija / Dr., Department of the History, Philosophy and Ethics of Medicine, Heinrich-Heine-University of Düsseldorf, Germany

\section{Yvonne Gavallèr,}

$M A$, Medicīnas vēstures, fillozofijas un ētikas katedra, Heinriha Heines Universitāte Diseldorfā, Vācija / MA, Department of the History, Philosophy and Ethics of Medicine, Heinrich-Heine-University of Düsseldorf, Germany

\section{Nils Hansson,}

Asoc. prof., Medicīnas vēstures, filozofijas un ētikas katedra, Heinriha Heines Universitāte Diseldorfā, Vācija / Assoc. Prof., Department of the History, Philosophy and Ethics of Medicine, Heinrich-Heine-University Düsseldorf, Germany 